\title{
NANOSIMS OPENS A NEW WINDOW FOR DECIPHERING ORGANIC MATTER IN TERRESTRIAL AND EXTRATERRESTRIAL SAMPLES *
}

\author{
DOROTHY Z. OEHLER, ${ }^{1}$ FRANÇOIS ROBERT, ${ }^{2}$ SMAIL \\ MOSTEFAOUI, ${ }^{2}$ ANDERS MEIBOM, ${ }^{2}$ MADELEINE SELO, ${ }^{2}$ \\ DAVID S. MCKAY, ${ }^{1}$ AND EVERETT K. GIBSON ${ }^{1}$ \\ ${ }^{1}$ Astromaterials Research and Exploration Science Directorate, NASA- \\ Johnson Space Center, Houston, Texas and ${ }^{2}$ Laboratoire d'Etude de la \\ Matière Extraterrestre, Muséum National d'Histoire Naturelle, Paris, \\ France.
}

\section{Introduction}

Recognition of the earliest morphological or chemical evidence of terrestrial life has proved to be challenging, as organic matter in ancient rocks is commonly fragmentary and difficult to distinguish from abiotically-produced materials (Schopf, 1993; Van Zuilen et al., 2002; Altermann \& Kazmierczak, 2003; Cady et al., 2003; Brasier et al., 2002, 2004, 2005; Hofmann, 2004; Skrzypczak et al., 2004, 2005). Yet, the ability to identify remnants of earliest life is critical to our understanding of the timing of life's origin on earth, the nature of earliest terrestrial life, and recognition of potential remnants of microbial life that might occur in extraterrestrial materials.

The search for earliest life on Earth now extends to early Archean organic remains; these tend to be very poorly preserved and considerably more difficult to interpret than the delicately permineralized microfossils known from many Proterozoic deposits. Thus, recent efforts have been directed toward finding biosignatures that can help distinguish fragmentary remnants of ancient microbes from either pseudofossils or abiotic organic materials that may have formed hydrothermally or in extraterrestrial processes (House et al., 2000; Boyce et al., 2001; Kudryavtsev et al., 2001; Schopf, 2002; Schopf et al., 2002, 2005a,b; Cady et al., 2003; García-Ruiz et al., 2003; Hofmann, 2004; Brasier et al., 2005; Rushdi and Simoneit, 2005; Skrzypczak et al., 2005).

An exciting area of biosignature research involves the developing technology of NanoSIMS. NanoSIMS is secondary ion mass spectrometry (SIMS) for ultrafine feature, elemental and isotopic analysis. Its resolution approaches $0.05 \mu \mathrm{m}$ for element mapping, which is $10-50$ times finer than that attainable with conventional

* Adapted from Oehler, D.Z., Robert, F., Mostefaoui, S., Meibom, A., Selo, M. and McKay, D.S. (2006), Chemical Mapping of Proterozoic Organic Matter at Submicron Spatial Resolution, Astrobiology 6 (6): 838-850. Permission to reprint portions of that article has been granted by Mary Ann Liebert, Inc., publisher of Astrobiology. 
SIMS or electron microprobes. Consequently, NanoSIMS has the potential to reveal previously unknown, chemical and structural characteristics of organic matter preserved in geologic materials.

Robert et al. (2005) were the first to combine NanoSIMS element maps with optical microscopic imagery in an effort to develop a new method for assessing biogenicity. They showed that the ability to simultaneously map the distribution of "organic" elements [such as carbon $(\mathrm{C})$, nitrogen $(\mathrm{N})$, and sulfur $(\mathrm{S})$ ] and compare those element distributions with optically recognizable, cellularly preserved fossils could provide significant new insights into the origin of organic materials in ancient sediments.

This chapter details a recent NanoSIMS study which was designed to acquire new data relevant to establishing critical biosignatures (Oehler et al., 2006a-c). In this study, NanoSIMS was used to characterize element distributions of spheroidal and filamentous microfossils and associated organic laminae in chert from the $\sim 0.85$ billion year old $(\mathrm{Ga})$ Bitter Springs Formation of Australia. Previous work established preservation of a diverse microbiota in the Bitter Springs Formation (Schopf, 1968; Schopf and Blacic, 1971), and there is no dispute within the scientific community regarding the biogenicity of any of the Bitter Springs structures evaluated in this new study. Thus, the NanoSIMS results described below provide new insight into - and can be used as a guide for assessing - the origin of less well understood organic materials that may occur in early Archean samples and in meteorites or other extraterrestrial samples.

\section{Materials and Methods}

Analysis was performed on structures within a polished thin section, $\sim 30 \mu \mathrm{m}$ thick, of chert, collected by D.Z. Oehler from the Ellery Creek locality of the Bitter Springs Formation. For the current study, spheroidal ( $c f$. Myxococcoides) and filamentous ( $c f$. Eomycetopsis) microfossils as well as organic laminae were located within the section using optical microscopy (Fig. 1). Specimens were selected for NanoSIMS based on the quality of preservation and occurrence at the top surface of the thin section. The specimens were photographed using an Olympus BX60 Research and Polarizing Optical Microscope, outfitted with a Nikon DXM 1200F Digital Camera; $4 \times, 10 \times$, and 40× dry objectives were used, in both transmitted and reflected light, and sketch maps were constructed for use with the photographs for locating the structures of interest in the NanoSIMS instrument. Photomicrographic focal series were taken (using the same optical microscope) from the top of the thin section to the base of the structures of interest in transmitted light, using a 100× oil immersion lens and Cargill type DF immersion oil (Formula Code 1261). Focal planes imaged spanned about $20 \mu \mathrm{m}$ of the thin section, and eight to 12 images typically were taken, so that step size between individual images of a focal series was $1-3 \mu \mathrm{m}$. The thin section was subsequently cleaned to remove all oil and any contamination from fingerprints by ultrasonication five times with reagent-grade ethanol for $2 \mathrm{~min}$, each time. After the sample was cleaned with ethanol, it was dried in a $60^{\circ} \mathrm{C}$ oven for $1 \mathrm{~h}$ to drive off all solvents and finally coated with about $300 \AA$ of gold.

It was assumed that the ultrasonication procedure was adequate to remove any traces of immersion oil or fingerprints on the slide. This assumption seems reasonable in 

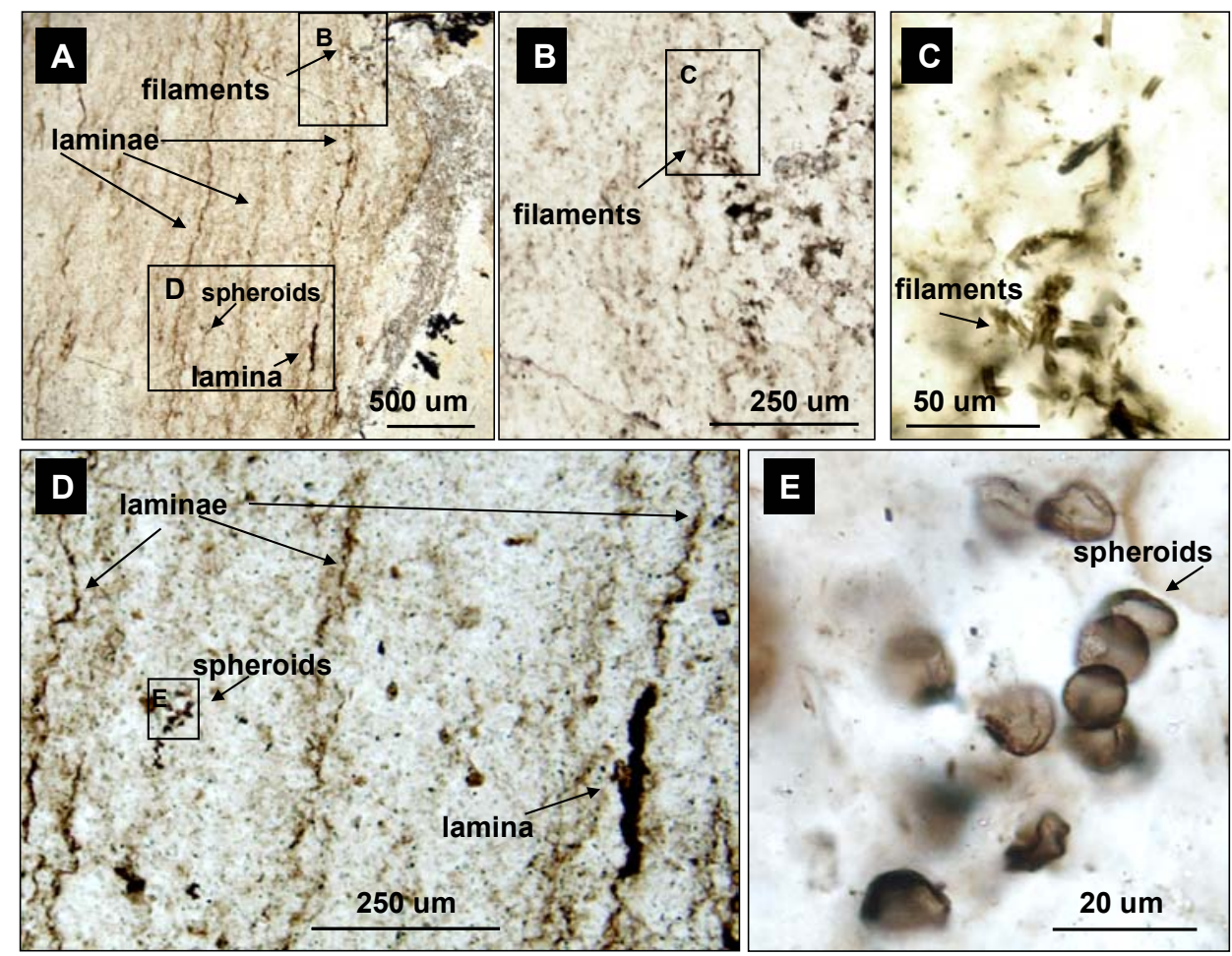

Figure 1. Optical photomicrographs in transmitted light of organic spheroids, filaments, and laminae in a polished thin section of chert from the $\sim 0.85 \mathrm{Ga}$ Bitter Springs Formation. (A-E) illustrate the spatial relationships among the different types of structures discussed in this paper. The small rectangles in (A) identify fields of view in (B) and (D), the small rectangle in (B) identifies the field of view in (C), and the small rectangle in (D) identifies the field of view in (E).

view of the facts that (1) the NanoSIMS carbon maps are mirrored by both $\mathrm{N}$ and $\mathrm{S}$ maps (which is suggestive of sedimentary organic matter rather than the immersion oil, which is composed of hydrocarbons and chlorinated hydrocarbons), (2) there is a oneto-one correspondence of the $\mathrm{C}, \mathrm{S}$, and $\mathrm{N}$ maps with organic, kerogenous structures seen optically, and (3) the initial sputtering by NanoSIMS removes the most surficial layer, so any surface contamination is removed before data are collected. In addition, none of the kerogenous structures imaged resides in any sort of a crack in the thin section, where traces of immersion oil conceivably could remain. Finally, it should be noted that the thin section studied was not embedded with epoxy during the thin sectioning process, as the sample was relatively dense, indurated and unfractured, so that none of the NanoSIMS data could be interpreted as originating from either epoxy or some combination of epoxy and immersion oil.

Chemical maps were produced with the Cameca NanoSIMS 50 of the Muséum National d'Histoire Naturelle in Paris, France. Using a focused primary beam of $\mathrm{Cs}^{+}$, secondary ions were sputtered from the sample surface. ${ }^{12} \mathrm{C}^{-},{ }^{12} \mathrm{C}^{14} \mathrm{~N}^{-},{ }^{32} \mathrm{~S}^{-},{ }^{28} \mathrm{Si}^{-}$, and ${ }^{16} \mathrm{O}^{-}$or ${ }^{18} \mathrm{O}^{-}$were detected simultaneously (multicollection-mode) in electron-multipliers 
at a mass-resolving power of $\sim 4,500(M / M)$. At this mass-resolving power, the measured secondary ions were resolved from potential interference by other ions or molecules that fall close in mass to the ions of interest. Because nitrogen is detected as $\mathrm{CN}^{-}$in NanoSIMS instruments, it can only be detected in the presence of carbon. Images were obtained from a presputtered surface area by stepping the primary beam across the sample surface. Presputtering is done to remove the conductive coating and clean the surface of any contaminants before analysis. The primary beam was focused to a spot size of $\sim 50-100 \mathrm{~nm}$, and the step size was adjusted so that it was comparable to, but slightly smaller than, the size of the primary beam. An electron gun supplied electrons to the sputtered surface during analysis to compensate for positive charge deposition from the primary beam and to minimize specimen charging effects. Followup scanning electron microscopy was performed on the Jeol JSM-5910LV (at $15 \mathrm{kV}, 10$ $\mathrm{mm}$ W.D.) at Johnson Space Center, Houston, TX.

$\mathrm{N} / \mathrm{C}$ atomic ratios were obtained from measured ${ }^{12} \mathrm{C}^{14} \mathrm{~N}^{-}$and ${ }^{12} \mathrm{C}^{-}$yields by normalization to a kerogen standard that we prepared from a sample of the Eocene Green River Shale. This kerogen, which was extracted from the shale by standard HF$\mathrm{HCl}$ techniques (Beaumont and Robert, 1999), comprised $\geq 94 \%$ of the acid-insoluble residue; standard chemical techniques (Beaumont and Robert, 1999) were used to determine that the kerogen has an atomic $\mathrm{N} / \mathrm{C}$ ratio of 0.025 . The ${ }^{12} \mathrm{C}^{14} \mathrm{~N}^{-} /{ }^{12} \mathrm{C}^{-}$ratio of the standard was then measured in the NanoSIMS using operating conditions identical to those used for analyzing the Bitter Springs fossils (e.g., same presputtering, spot size, e-gun, etc.).

Figure 1 illustrates the different types of organic structures analyzed in the thin section and their spatial relationships to one another. The spheroids studied are fairly abundant and occur in clusters of a few to $\sim 25$ cells, most commonly between dark brown organic laminae; the cells are typically less than $10 \mu \mathrm{m}$ in diameter and have distinct reticulate walls, $0.3-0.5 \mu \mathrm{m}$ thick. The filaments consist of sinuous hollow tubes, are also abundant in the thin section, and occur intertwined in mat-like layers that grade into the dark organic laminae; the filaments are 3-5 $\mu \mathrm{m}$ in diameter, up to hundreds of microns long, and have somewhat diffuse granular walls, 0.4-0.7 $\mu \mathrm{m}$ thick. The organic laminae are planar features composed of morphologically indistinct organic material, as seen in optical microscopy. In thin section, they appear as strand-like fragments of organic matter that align to form parallel, wavy to crenulate surfaces. The material making up the laminae varies from morphologically diffuse and semitransparent to more distinct-bordered and dark brown in color. The laminae occur at intervals of a fraction of a millimeter to a few millimeters, and they have thicknesses from about 5 to $20 \mu \mathrm{m}$.

\section{Results}

NanoSIMS maps of $\mathrm{C}, \mathrm{N}, \mathrm{S}, \mathrm{Si}$, and $\mathrm{O}$ (measured as ${ }^{12} \mathrm{C}^{-},{ }^{12} \mathrm{C}^{14} \mathrm{~N}^{-},{ }^{32} \mathrm{~S}^{-},{ }^{28} \mathrm{Si}^{-}$, and ${ }^{16} \mathrm{O}^{-}$or ${ }^{18} \mathrm{O}^{-}$) were acquired of the spheroidal and filamentous organic microfossils and the apparently amorphous organic laminae from a single thin section of the Bitter Springs Formation (Figs. 2-7). Results demonstrate an excellent correspondence between the optical images of the microfossils and the spatial (two-dimensional) distributions of $\mathrm{C}^{-}$, 


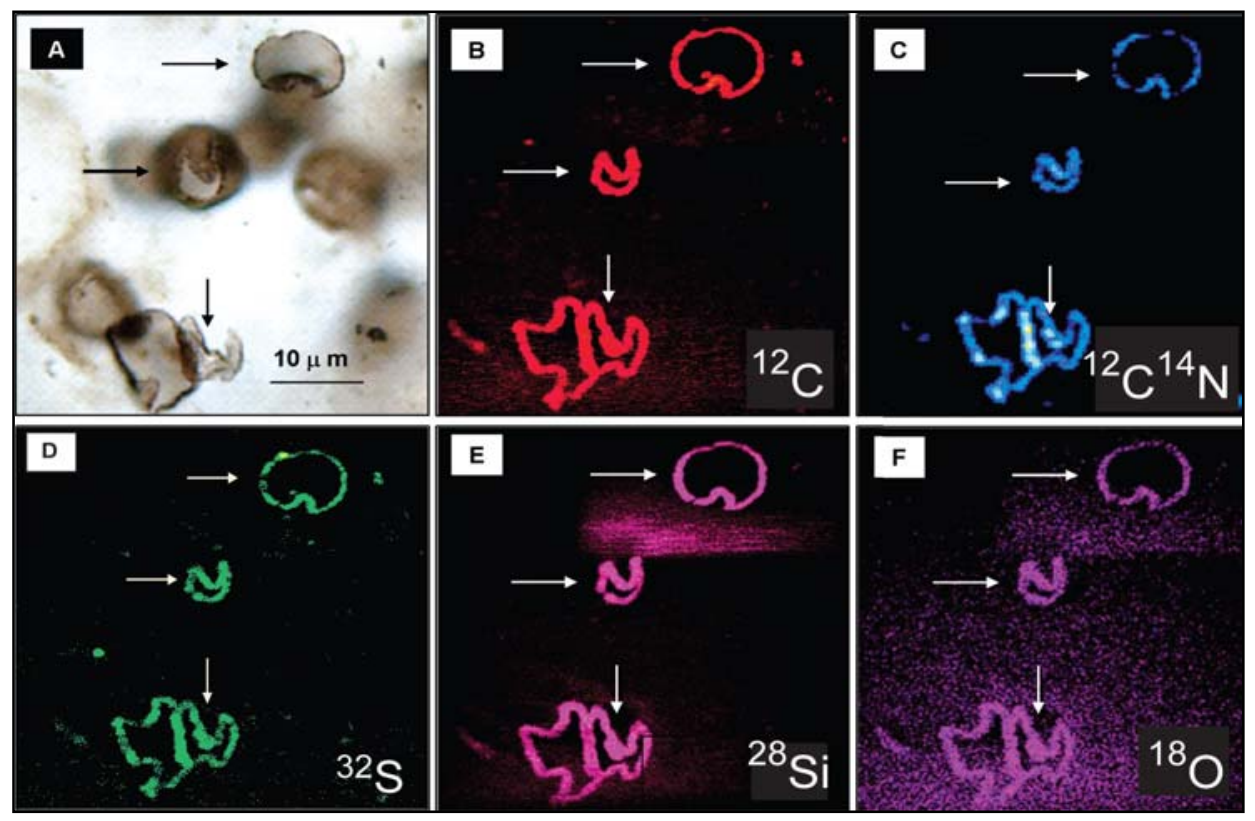

Figure 2. Spheroidal organic microfossils in a polished thin section of chert from the Bitter Springs Formation. (A) Optical photomicrograph in transmitted light; the cells of this panel are part of the cluster illustrated in Fig. 1A and E, but at a different focal plane and rotated so that the optical and NanoSIMS images can be directly compared. (B-F) NanoSIMS element maps of the same area as in (A). Arrows show corresponding cells in the different panels. Scale in (A) applies to all. ${ }^{12} \mathrm{C}$, carbon; ${ }^{12} \mathrm{C}^{14} \mathrm{~N}$, nitrogen measured as $\mathrm{CN}^{-}$ion; ${ }^{32} \mathrm{~S}$, sulfur; ${ }^{28} \mathrm{Si}$, silicon; ${ }^{18} \mathrm{O}$, oxygen. Color scheme is red for carbon, blue for nitrogen, green for sulfur, pink for silicon, and lavender for oxygen. The more intense the color, the stronger the response, with white being the strongest response in all cases.

$\mathrm{CN}^{-}$, and $\mathrm{S}^{-}$(Figs. 2-4). Intense sputtering into one sample allowed penetration by the NanoSIMS to a focal plane, $2-3 \mu \mathrm{m}$ deeper in the section. A comparison of the optical image at a similar focal plane with the $\mathrm{C}^{-}, \mathrm{CN}^{-}$, and $\mathrm{S}^{-}$maps at that lower plane in the NanoSIMS also demonstrates a three-dimensional correspondence between results of NanoSIMS and optical microscopy (Fig. 3). Importantly, the host chert matrix is essentially lacking in significant $\mathrm{C}^{-}, \mathrm{CN}^{-}$, and $\mathrm{S}^{-}$, and these ions are present only in structures identified as microfossils using optical microscopy (Fig. 2).

Ultra-high-resolution images (obtained with the smallest possible primary beam spot, around $50 \mathrm{~nm}$ in diameter, which was rastered over a small area, typically $10 \times 10 \mu \mathrm{m}^{2}$, in order to collect sufficient secondary ions from each pixel) show that the $\mathrm{C}^{-}, \mathrm{CN}^{-}$, and $\mathrm{S}^{-}$distributions are identical to one another for both the spheroidal and the filamentous microfossils (Figs. 5 and 6). The spheroidal microfossils are defined by wall-like structures that consist of distinct globules enriched in $\mathrm{C}^{-}, \mathrm{CN}^{-}$, and $\mathrm{S}^{-}$(Fig. 5). In contrast, the filamentous microfossils appear to consist of more diffuse, irregular, and "less packaged" material enriched in $\mathrm{C}^{-}, \mathrm{CN}^{-}$, and $\mathrm{S}^{-}$(Fig. 6). These observations are likely to reflect differences in the structures of the biological precursors of the two types of microfossils: the spheroidal microfossils comprising remnants of actual cell walls and 


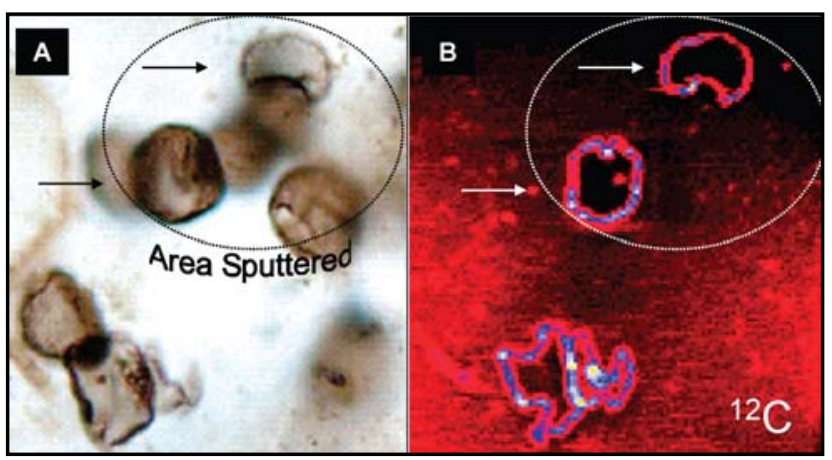

Figure 3. Spheroidal organic microfossils in a polished thin section of chert from the Bitter Springs Formation. (A) Optical photomicrograph in transmitted light, focused at a plane slightly below that of Fig. 2A. Dotted oval indicates area sputtered in the NanoSIMS. (B) NanoSIMS map, illustrating carbon image after sputtering into the thin section to a focal plane similar to that illustrated in (A). Nitrogen and sulfur maps (not shown) were similar to the carbon map. Arrows show corresponding cells in (A) and (B) and in Fig. 2.

${ }^{12} \mathrm{C}$, carbon. Color scheme is red for carbon. The more intense the color, the stronger the response, with white being the strongest response in all cases.

the filamentous forms probably representing remnants of extracellular mucilaginous sheaths common to filamentous cyanobacteria.

The $\mathrm{Si}^{-}$and $\mathrm{O}^{-}$maps also reflect the morphology of the microfossils (Fig. 2), even though some $\mathrm{Si}^{-}$and $\mathrm{O}^{-}$yields are detected from the host chert $\left(\mathrm{SiO}_{2}\right)$ as well (Fig. 5F). However, in the higher-resolution images of Figs. 5 and 6, the $\mathrm{Si}^{-}$and $\mathrm{O}^{-}$yields display differences in detail from the distributions of $\mathrm{C}^{-}, \mathrm{CN}^{-}$, and $\mathrm{S}^{-}$. In the spheroids, the $\mathrm{Si}^{-}$ distribution shows a more open texture than is apparent in the $\mathrm{C}^{-}$map (cf. Fig. 5A and $\mathrm{B}$ ), and in the highest resolution (Fig. 5E and F), the globules of $\mathrm{Si}^{-}$alternate spatially with globules of $\mathrm{C}^{-}$. In the filaments, $\mathrm{Si}^{-}$and $\mathrm{O}^{-}$distributions appear to be thicker and more continuous than the simultaneously collected $\mathrm{C}^{-}, \mathrm{CN}^{-}$, or $\mathrm{S}^{-}$ions $(c f$. Fig. $6 \mathrm{~B}-\mathrm{D}$ with Fig. 6E and F).

The NanoSIMS elemental maps of the organic laminae exhibit relationships among $\mathrm{C}^{-}, \mathrm{CN}^{-}, \mathrm{S}^{-}, \mathrm{Si}^{-}$, and $\mathrm{O}^{-}$similar to those observed in the spheroids and filaments, and the images show densely packed structures reminiscent of the filamentous microfossils and collapsed spheroids (Fig. 7).

$\mathrm{CN}^{-} / \mathrm{C}^{-}$ratios of the spheroids, filaments, and laminae were measured in multiple localities on the NanoSIMS maps. Results show major differences in both absolute values and ranges (Table 1$)$.

\section{Discussion}

For spheroidal and filamentous microfossils, the NanoSIMS $\mathrm{C}^{-}$and $\mathrm{S}^{-}$distributions are virtually identical to each other and to the $\mathrm{CN}^{-}$distributions, and a one-to-one correspondence exists with optical microscopic images (Figs. 2-6). This suggests that all three elements $(\mathrm{C}, \mathrm{N}$, and $\mathrm{S})$ are primarily remnants of biogenic organic matter. The size, shape, texture, and nature of the boundaries of the nanoscale remnants of $\mathrm{C}, \mathrm{N}$, and 

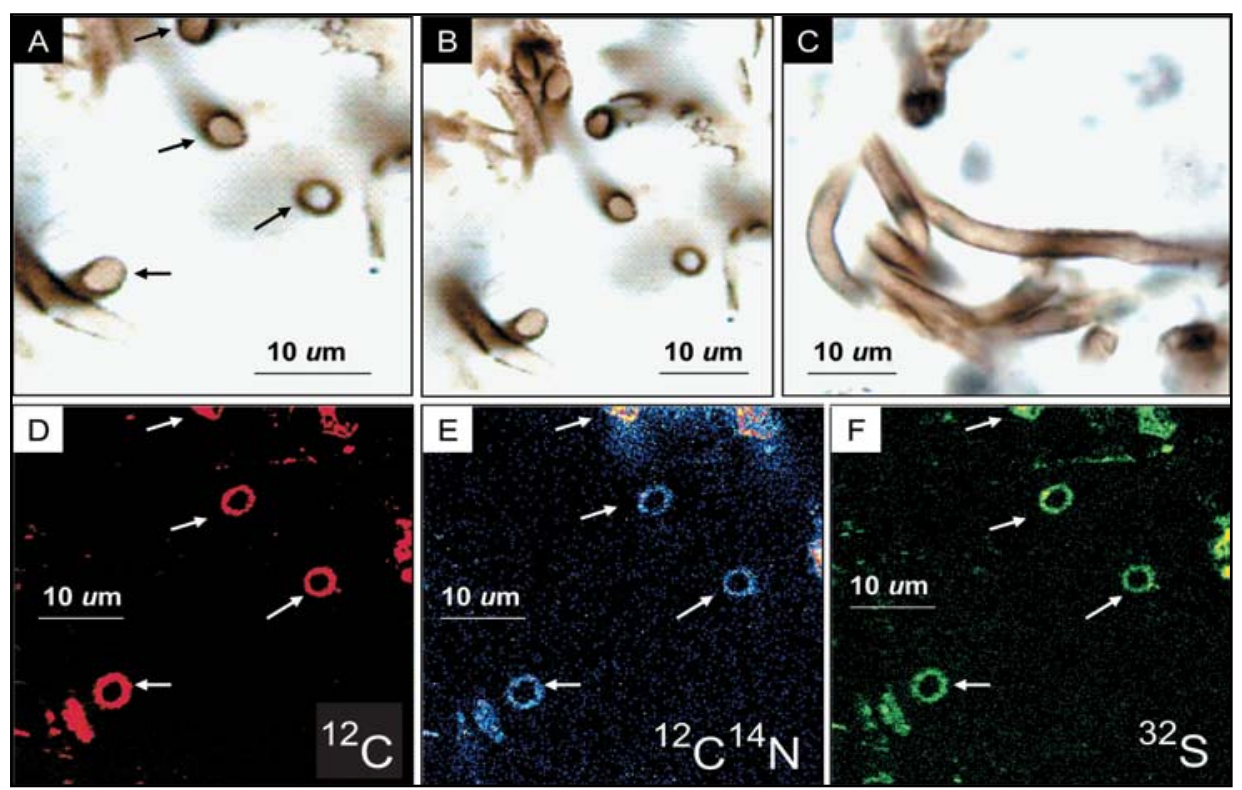

Figure 4. Filamentous microfossils in a polished thin section of chert from the Bitter Springs Formation. (A-C) Optical photomicrographs in transmitted light; (B) and (C) are at lower magnifications to illustrate the tube-like morphology and intertwined habit of these fossils. These filaments are part of the mass of filaments illustrated in Fig. 1A-C but at a different focal plane and rotated slightly so that the optical and NanoSIMS images can be compared. (C) is about $20 \mu \mathrm{m}$ below the focal plane of (A) (but in the exact same locality of the thin section), and a focal series of 11 photomicrographs, each taken successively 1-3 $\mu \mathrm{m}$ lower in the section, demonstrates that these filaments form an entangled mass throughout the entire $20 \mu \mathrm{m}$ that was imaged. (D-F) NanoSIMS element maps. Arrows show corresponding cells in the different panels. ${ }^{12} \mathrm{C}$, carbon; ${ }^{12} \mathrm{C}^{14} \mathrm{~N}$, nitrogen measured as $\mathrm{CN}^{-}$ion; ${ }^{32} \mathrm{~S}$, sulfur. Color scheme is red for carbon, blue for nitrogen, and green for sulfur. The more intense the color, the stronger the response, with white being the strongest response in all cases.

$\mathrm{S}$ of the filaments and spheroids constitute biosignatures for sedimentary remnants of these Proterozoic microorganisms.

Nitrogen is a good indicator of organic material because it is common in organic matter but rare in rock-forming minerals. Because nitrogen in rocks commonly derives from biological fixation processes, it can be considered an indicator of biological activity when associated with organic remains. While some chemical reactions might produce abiotic organics with nitrogen under certain hydrothermal or extraterrestrial conditions (Brearley, 2003; Ueno et al., 2004; Remusat et al., 2005), nitrogen associated with amorphous carbon in sedimentary rocks is most likely to be an indicator of biogenicity.

The $\mathrm{S}^{-}$probably represents a mixture of cellular sulfur with sulfur incorporated during early diagenesis by the common process of sulfurization (Kohnen et al., 1989; Eglinton et al., 1993; Werne et al., 2000; Brocks and Summons, 2003). While not completely understood, the process of sulfurization is thought to incorporate sulfur derived from pre-existing microbial remains or biologically reduced sulfur and reactive, inorganic sulfur species [e.g., from sulfate-reducing bacteria (Werne, 2002)]. Given the 

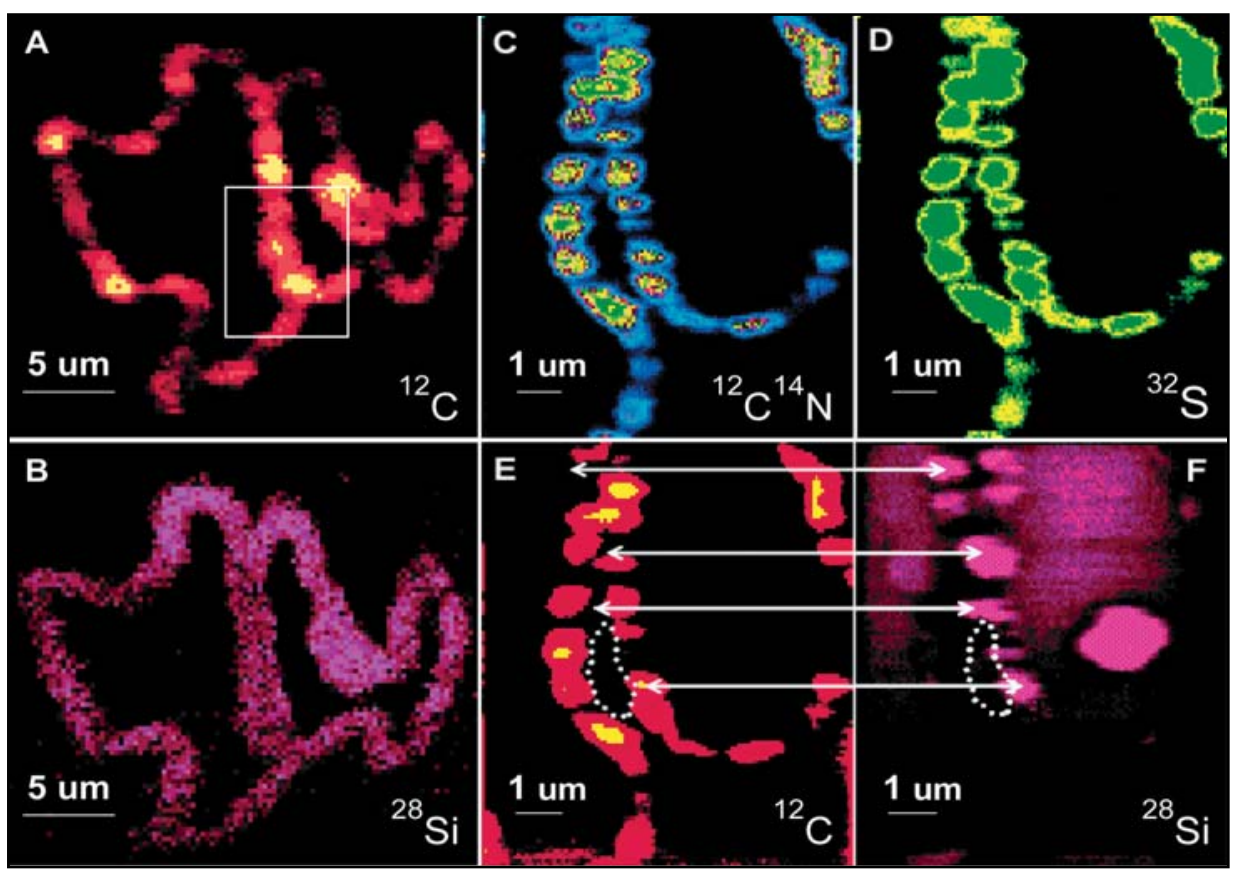

Figure 5. NanoSIMS images of a wall contact between two spheroidal microfossils in chert from the Bitter Springs Formation. (A and B) Relatively low magnification element maps. (C-F) High-resolution element maps. White rectangle in (A) shows area of high-resolution images in (C-F). Arrows in (E and F) tie locations of the silicon globules in $(\mathrm{F})$ with corresponding locations on the carbon map in $(\mathrm{E})$. In $(\mathrm{F})$, the diffuse area of Si response in the central portions of the spheroids is likely due to silica in the host chert. Dotted white ovals in (E and F) are reference areas to tie the two images for comparison. ${ }^{12} \mathrm{C}$, carbon; ${ }^{12} \mathrm{C}^{14} \mathrm{~N}$, nitrogen measured as $\mathrm{CN}^{-}$ion; ${ }^{32} \mathrm{~S}$, sulfur; ${ }^{28} \mathrm{Si}$, silicon. Color scheme is red for carbon, blue for nitrogen, green for sulfur, and pink for silicon. The more intense the color, the stronger the response, with white being the strongest response in all cases.

low metamorphic grade of the Bitter Springs Formation (Schopf et al., 2005b), the added sulfur is unlikely to have been derived from thermochemically produced $\mathrm{H}_{2} \mathrm{~S}$ or volcanic sources. Therefore, the sulfur, though partially secondary, is nevertheless likely to be an indicator of microbial activity.

The general correspondence of relatively high $\mathrm{Si}^{-}$and $\mathrm{O}^{-}$yields with the microfossils was a surprise (Figs. 2E and F, 6E and F, and 7E and F). This is partly a reflection of the contrast that was used to illustrate those images. In Fig. 5F, for example, a background response for $\mathrm{Si}^{-}$and $\mathrm{O}^{-}$from chert can be seen within the cells imaged. The enhanced yields of $\mathrm{Si}^{-}$and $\mathrm{O}^{-}$associated mainly with the organic matter may be ascribed to (1) a matrix effect, in which secondary $\mathrm{Si}^{-}$and $\mathrm{O}^{-}$yields are greater in organic-rich regions compared with areas of "pure" chert lacking organic material and/or (2) the silicification process, whereby silica has nucleated on organic surfaces during permineralization (Oehler and Schopf, 1971; Oehler, 1976; Benning et al., 2002; Phoenix et al., 2000, 2002; Toporski et al., 2002; Yee et al., 2003), and as a result, the $\mathrm{Si}^{-}$and $\mathrm{O}^{-}$concentrations are actually greater in the region of organic matter compared 
with the concentrations imaged from the chert. Both processes may be at work, and follow-up studies will be aimed at investigating this further.

$\mathrm{N} / \mathrm{C}$ ratios determined for the different structures range over two orders of magnitude, and such large variations are likely to be significant (Table 1), though we caution that the $\mathrm{N} / \mathrm{C}$ results are preliminary. There are two types of instrumental fractionation (referred to as "matrix effects") that might affect measured $\mathrm{CN}^{-} / \mathrm{C}^{-}$and, therefore, the calibrated $\mathrm{N} / \mathrm{C}$ ratios. These can occur because (1) the kerogen that makes up the microfossils and organic laminae is measured in its matrix of silica, while the standard was measured in purified acid extracts, and (2) the standard is an Eocene type I kerogen from the Green River Shale (i.e., rich in aliphatic chains), whereas kerogen in the nearly 1 billion year old Bitter Springs chert is likely to be much more aromatic. However, such matrix effects typically only result in differences of a few percent, and so it is highly unlikely that such effects could account for the two-orders-of-magnitude variation among the measured $\mathrm{CN}^{-} / \mathrm{C}^{-}$ratios of the different Bitter Springs structures. Thus, the large disparity in $\mathrm{CN}^{-} / \mathrm{C}^{-}$ratios of the Bitter Springs spheroids, filaments, and laminae is likely to be real.

TABLE 1. Nitrogen to Carbon Ratios

\begin{tabular}{lllll}
\hline Sample & Measured $\mathrm{CN}^{-} / \mathrm{C}^{-}$ & N/C (atomic) & \\
& & & & \\
\hline Kerogen standard & $0.414 \pm 0.083$ & & 0.025 & \\
\hline & Minimum & Maximum & Minimum & Maximum \\
\hline Filaments & $0.02 \pm 0.008$ & $0.04 \pm 0.016$ & $0.0012 \pm 0.00048$ & $0.0024 \pm 0.00097$ \\
Spheroids & $0.12 \pm 0.047$ & $0.22 \pm 0.086$ & $0.0073 \pm 0.00284$ & $0.0133 \pm 0.00519$ \\
Laminae & $0.12 \pm 0.047$ & $1.00 \pm 0.039$ & $0.0073 \pm 0.00284$ & $0.0604 \pm 0.00236$ \\
\hline
\end{tabular}

In addition, the $2 \sigma$ error calculated for the $\mathrm{CN}^{-} / \mathrm{C}^{-}$of the kerogen standard includes the statistical ion counting and the reproducibility determined by measuring four different locations on the standard; that is $\mathrm{CN}^{-} / \mathrm{C}^{-}=0.414 \pm 0.083(2 \sigma)$. The $2 \sigma$ errors reported for $\mathrm{CN}^{-} / \mathrm{C}^{-}$measured in multiple locations in each type of Bitter Springs structure would include similar effects (Table 1). In summary, while the statistical error on the standard can be used for precise comparisons with statistical errors determined for measured $\mathrm{CN}^{-} / \mathrm{C}^{-}$of Bitter Springs structures, the $\mathrm{N} / \mathrm{C}$ atomic ratios determined for the structures should be regarded as semi-quantitative estimates.

The $\mathrm{CN}^{-} / \mathrm{C}^{-}$ratios of the filaments were found to be significantly lower $(0.02-0.04)$ than the ratios of the spheroids $(0.12-0.22)$. This difference is unlikely to be attributable to subtle diagenetic differences (since all structures are from the same thin section), and there is no evidence of hydrothermal activity or meteoritic contribution, which could account for abiotic formation of organic compounds. Thus, the large disparity in the $\mathrm{CN}^{-} / \mathrm{C}^{-}$ratios would seem likely to reflect original differences in the biological precursor materials. This interpretation is consistent with the preservation of an exopolysaccharide precursor for the sheath-like material, which would have surrounded the living filaments, and a peptidoglycan precursor (with much higher expected nitrogen content) for the material that would have been contained in the outer cell walls of the spheroids. 

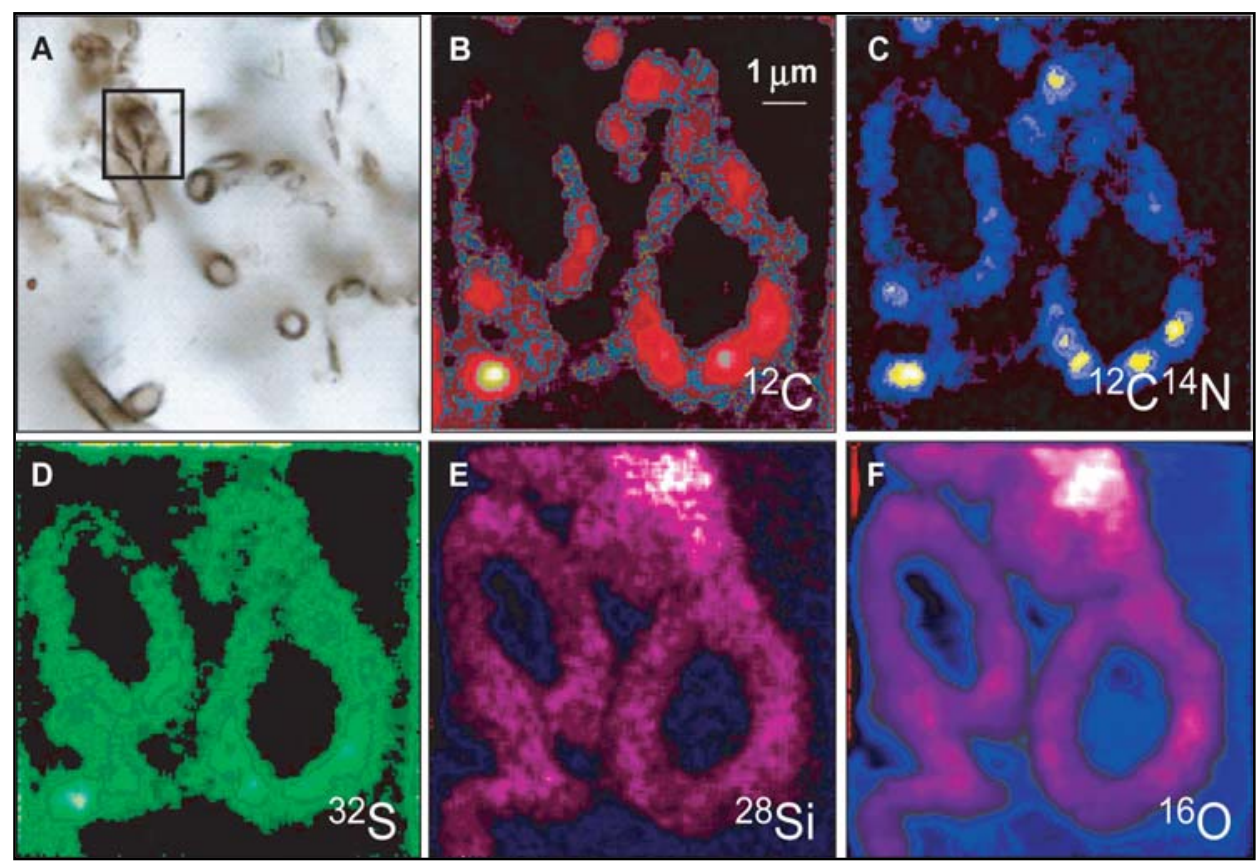

Figure 6. Filamentous microfossils in a polished thin section of chert from the Bitter Springs Formation. (A) Optical photomicrograph in transmitted light. (B-F) High-resolution NanoSIMS element maps. Black rectangle in (A) shows area of detail in (B-F). Scale in (B) applies to $(\mathrm{B}-\mathrm{F}) .{ }^{12} \mathrm{C}$, carbon; ${ }^{12} \mathrm{C}^{14} \mathrm{~N}$, nitrogen measured as $\mathrm{CN}^{-}$ion; ${ }^{32} \mathrm{~S}$, sulfur; ${ }^{28} \mathrm{Si}$, silicon; ${ }^{16} \mathrm{O}$, oxygen. Color scheme is red for carbon, blue for nitrogen, green for sulfur, pink for silicon, and lavender for oxygen. The more intense the color, the stronger the response, with white being the strongest response in all cases.

Similarly, a disparity in the original chemistry of the two types of microfossils may explain the apparently thicker and more continuous pattern of silicification in the filaments compared to that in the spheroids ( $c f$. Figs. $6 \mathrm{E}$ and $\mathrm{F}$ and $5 \mathrm{~A}, \mathrm{~B}$, and $\mathrm{F}$ ). If the filamentous forms are remnants of mucilaginous sheaths, then their originally exopolysaccharide chemistry may have promoted more extensive silicification (by a combination of permeation and encrustation) than occurred on the peptidoglycan of the walls of the spheroids. This possibility is suggested by artificial permineralization studies in which laboratory-fossilized microbial filaments with sheaths were both encrusted and permeated by silica (Oehler, 1976). It is supported further by recent studies showing that active permineralization favors exopolysaccharides of cyanobacterial sheaths (Phoenix et al., 2000, 2002; Yee et al., 2003).

Surprisingly, the organic laminae contain filamentous and apparently compressed spheroidal structures that are defined by strong enrichments in $\mathrm{C}^{-}, \mathrm{CN}^{-}$, and $\mathrm{S}^{-}$(Fig. 7). These microfossil-like structures in the organic laminae are also characterized by sizes and thicknesses reminiscent of the well-preserved microfossils in the mineral matrix of the rocks (cf. Figs. 2, 4, and 7). Thus, the laminae are interpreted as most likely representing remnants of densely packed microbial mats. This conclusion is consistent with the generally accepted view that such laminae are derived from biological 

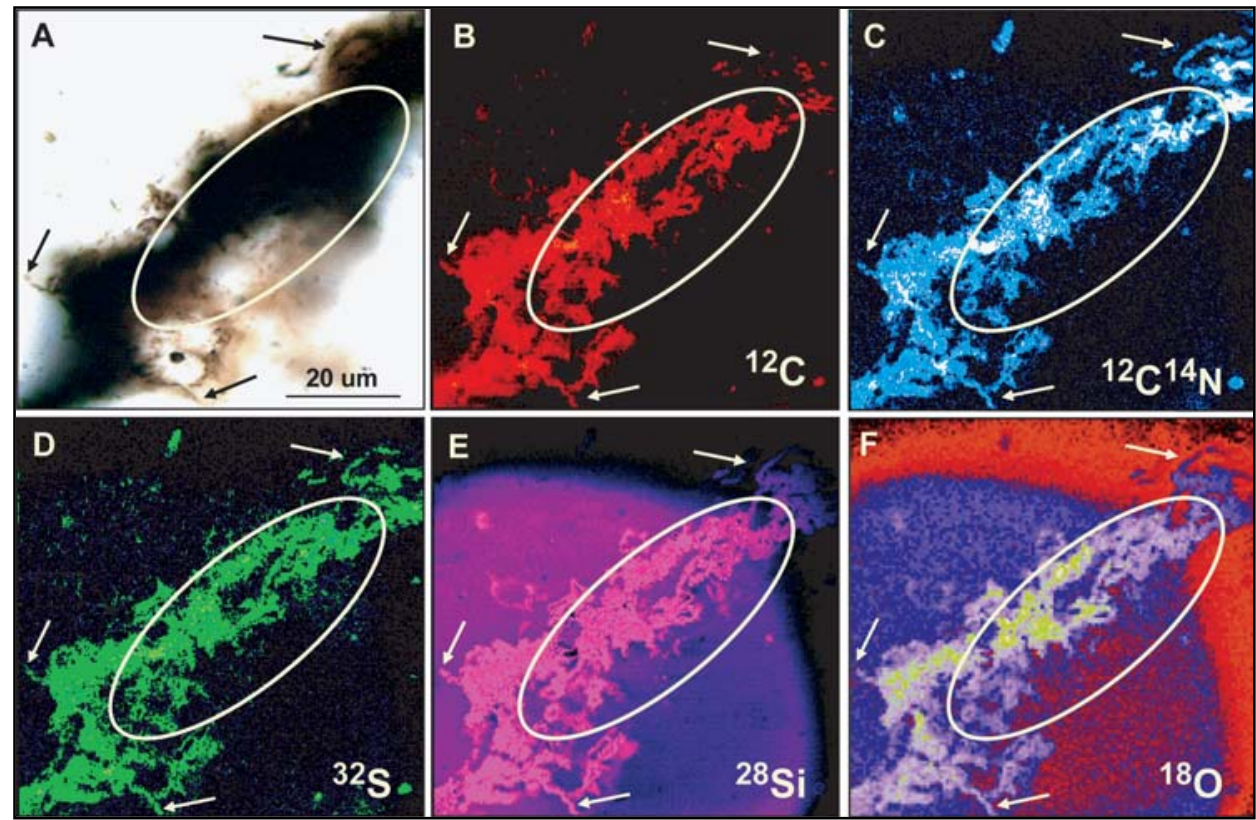

Figure 7. Organic lamina in a polished thin section of chert from the Bitter Springs Formation. (A) Optical photomicrograph in transmitted light; the location of this lamina and its spatial relationship to other structures discussed is illustrated in Fig. 1A and D. (B-F) NanoSIMS element maps of the area in (A). Arrows show reference points for comparison. The white ovals show the same region in (A-F). Scale in (A) applies to all. Sputtered areas are particularly evident in (E and F) as the large circular regions that extend well beyond the lamina. ${ }^{12} \mathrm{C}$, carbon; ${ }^{12} \mathrm{C}^{14} \mathrm{~N}$, nitrogen measured as $\mathrm{CN}^{-}$ion; ${ }^{32} \mathrm{~S}$, sulfur; ${ }^{28} \mathrm{Si}$, silicon; ${ }^{18} \mathrm{O}$, oxygen. Color scheme is red for carbon, blue for nitrogen, green for sulfur, pink for silicon, and lavender for oxygen. The more intense the color, the stronger the response, with white being the strongest response in all cases.

precursors that are simply less well preserved than the optically recognizable filaments and spheroids. Since obvious microfossils were not apparent within the laminae, using optical microscopy or scanning electron microscopy (Figs. 1 and 8), this result also demonstrated the potential of NanoSIMS to reveal new structure in kerogenous organic materials that were presumed to be generally amorphous.

$\mathrm{CN}^{-} / \mathrm{C}^{-}$and $\mathrm{N} / \mathrm{C}$ ratios for the laminae displayed higher absolute values and a much greater range than equivalent values from the individual spheroids and filaments (Table 1). The higher absolute values may reflect greater degradation in the laminae, which would result in increased $\mathrm{CN}^{-} / \mathrm{C}^{-}$values through oxidation of organic carbon and/or addition of nitrogen by microbial nitrification; such degradation also could account for the relatively poor state of preservation in the laminae, as noted above. The large range in $\mathrm{CN}^{-} / \mathrm{C}^{-}$values could also result from laminae that contain a mixture of microbial constituents; such a mixture might be composed of compressed filaments and spheroids that originally were similar in size and shape to the well-preserved microfossils and other microbial constituents of the ecosystem (e.g., Des Marais, 2003) or possible remnants of biofilms. 


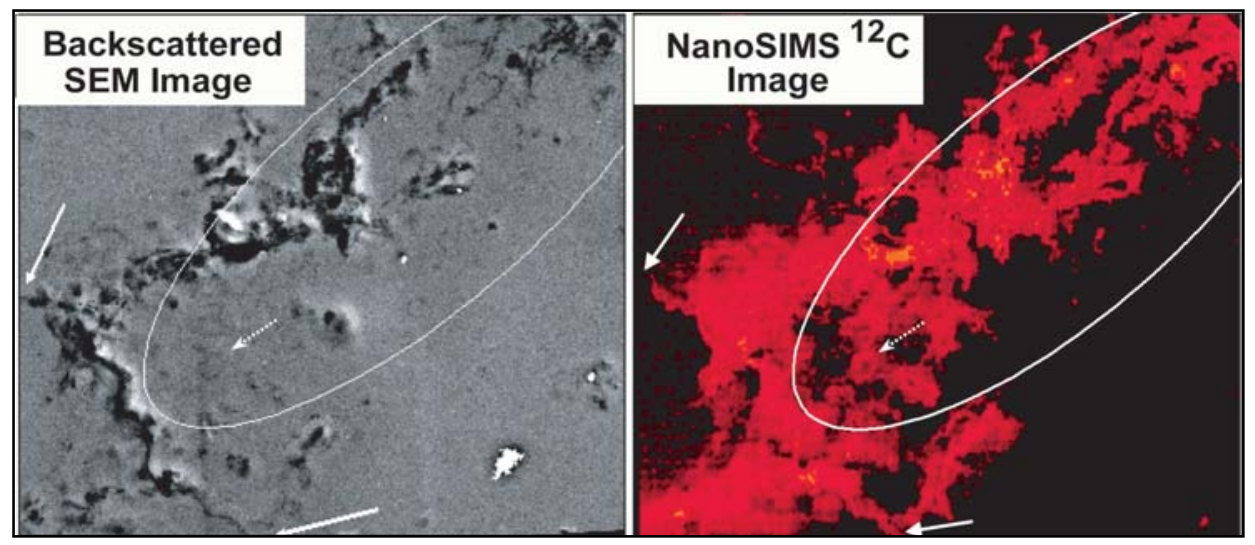

Figure 8. Scanning electron microscopy (SEM) (left) and NanoSIMS (right) comparison of organic lamina in a polished thin section of chert from the Bitter Springs Formation. The white ovals show the same area in each image and these ovals correspond to the ovals in Fig. 7; arrows show corresponding structures. The dashed arrows illustrate a structure suggestive of a cross section of a filament; in NanoSIMS, the structure is defined by $\mathrm{C}, \mathrm{CN}, \mathrm{S}, \mathrm{Si}$, and $\mathrm{O}$ enrichment (only $\mathrm{C}$ enrichment is illustrated here; see Fig. 7 for other element maps); in the backscattered SEM image, a faint hint of the same structure is seen.

Modern bacteria have N/C ratios that range from 0.15 to 0.28 (Fagerbakke et al., 1996; Fukuda et al., 1998), values that are much higher than those from either the individual microfossils or the laminae (overall range of $0.0012-0.0604$; Table 1). However, the N/C ratios from the laminae (0.0073-0.0604) overlap with the range of values reported in bulk kerogen samples from a variety of Precambrian cherts [0.00150.03 (Beaumont and Robert, 1999)]. The larger ranges of N/C ratios of the bulk kerogens and Bitter Springs laminae (compared to that reported for modern bacteria) likely represent a combination of (1) mixtures of precursor organisms, (2) early diagenetic changes that altered the original N/C ratios (for example, Gillaizeau et al., 1997; Bennett and Love, 2000), and (3) microbial degradation. Indeed, a large range in $\mathrm{N} / \mathrm{C}$ ratios, such as we have observed in the organic laminae, may be a characteristic and, thus, a biosignature of a degraded biological community.

\section{NanoSIMS of Organic Materials in Extraterrestrial Samples}

The sub-micron scale resolution of NanoSIMS is ideally suited to studying elemental and isotopic composition of organic material that is found in some extraterrestrial materials, and the technique is now being applied to gain information about the formation and occurrence of organic compounds in the solar system. Particularly interesting recent studies include 1) that by Nakamura-Messenger et al. (2006) on the Tagish Lake carbonaceous chondrite meteorite which found organic globules that might represent types of prebiotic carbon compounds that might have been delivered to a young Earth; 2) those of Floss and Stadermann (2005) and Floss et al. (2004) on organics in interplanetary dust particles; 3 ) recently-published first results on particles collected from Comet Wild 2 in the Stardust Mission (Sandford et al., 2006); and 4) 
ongoing work on organics in the Nakhla Martian meteorite (Gibson et al., 2006; McKay et al., 2006). Eventually, NanoSIMS-derived chemical composition will be compared for extraterrestrial organic materials and ancient terrestrial organic residues; these comparisons should provide new insight into the sources of organic materials on earth, their relationship to the evolution of life on earth, and the potential for development of life elsewhere in the solar system.

\section{Summary and Conclusions}

The results of the NanoSIMS study described have demonstrated that in situ elemental composition of Proterozoic microfossils can be mapped and quantified with NanoSIMS at a spatial resolution of about $50 \mathrm{~nm}$. The spatial correspondence of C, N, and $\mathrm{S}$, along with the $\mathrm{N} / \mathrm{C}$ ratios, provides new biosignatures for specific Proterozoic microorganisms and remnants of microbial communities. Moreover, N/C ratios as well as the distinctive patterns of silicification in the filaments and spheroids are suggestive of original differences in their chemical make-up (i.e., an exopolysaccharide precursor for the sheath-like filamentous forms vs. a peptidoglycan precursor for the walls of the spheroids). Finally, NanoSIMS images of organic laminae previously thought to be amorphous reveal structures suggestive of densely packed remnants of microorganisms. These results are particularly notable, as the preponderance of organic matter in sedimentary rocks of any age occurs as similarly "amorphous," fragmentary remains, even in deposits with coexisting, bona fide microfossils (see Fig. 1, as an example). Therefore, it is possible that NanoSIMS will provide fresh insight into a large body of previously uninterpretable material.

Nevertheless, these first chemical maps of fossil cells are just a beginning. There are two additional types of chemical analyses possible with NanoSIMS that could provide significant new information about the nature of the organisms that produced these fossils: Namely, sub-micron scale analyses of 1) stable isotope ratios of $\mathrm{H}, \mathrm{C}, \mathrm{N}$, and $\mathrm{S}$ and 2) elemental compositions of other potential indicators of biologic activity, such as $\mathrm{Mg}, \mathrm{Fe}$, and $\mathrm{P}$. Both could provide insight into the metabolic pathways utilized by the ancient organisms that are fossilized in Precambrian-aged sediments.

Future work will aim at characterization of microfossils and organic fragments in Precambrian sedimentary rocks of varying ages, depositional environments, and lithologies. Key to selection of structures for this characterization will be their undisputed biogenicity, so that results can be used as a guide to interpreting less wellpreserved, problematic materials. In situ stable isotope compositions from NanoSIMS will be performed and are expected to provide additional criteria for distinguishing biologically produced organic matter from that produced by abiotic mechanisms [e.g., $\delta^{15} \mathrm{~N}$ values of Precambrian kerogens generally are distinct from $\delta^{15} \mathrm{~N}$ of primitive organics in interplanetary dust particles and carbonaceous chondrites (Beaumont and Robert, 1999; Floss and Staderman, 2005; Remusat et al., 2005)]. And finally, elemental analyses of the other potential metabolic indicators, such as $\mathrm{Mg}, \mathrm{Fe}$, and $\mathrm{P}$, will be performed.

Thus, the new elemental and isotopic data obtainable with NanoSIMS will add significantly to the repository of criteria that can be used for assessing biogenicity and 
understanding the origin and significance of poorly preserved organic residues in some of the Earth's oldest rocks. In addition, establishment of nano-scale element and isotope ratios of early forms of life on earth and comparison with equivalent data from organic matter found in carbonaceous chondrites, Martian meteorites, cometary materials, and interplanetary dust particles, will provide new insight regarding the interplay of extraterrestrial organic compounds, the origin and early evolution of life on earth, and the potential for development of living systems on planetary bodies beyond earth.

\section{Acknowledgements}

We are grateful to Mary Ann Liebert, Inc. for granting permission to reprint sections of Oehler et al., 2006 (Astrobiology 6 (6): 838-850), on which much of this chapter is based. We thank the Astromaterials Research and Exploration Science (ARES) Directorate at NASA-Johnson Space Center (JSC) and Centre National de la Recherche Scientifique (CNRS) for support. We are grateful to Drs. Carlton C. Allen (NASA JSC), Malcolm Walter (Australian Centre for Astrobiology), and Jochen Brocks (Australian National University) for insightful comments and suggestions, and to Dr. Craig Schwandt and Ms. Georg Ann Robinson (JSC-ARES) for assistance with scanning electron microscopy. This work was partially supported by a PNP grant from the CNRS and NASA grant NRA-03-OSS-01-EXOB to D.S.M.

\section{References}

Altermann, W. and Kazmierczak, J. (2003). Archean microfossils: a reappraisal of early life on Earth. Research in Microbiology 154: 611-617.

Beaumont, V. and Robert, F. (1999) Nitrogen isotope ratios of kerogens in Precambrian cherts: a record of the evolution of atmosphere chemistry? Precambrian Res. 96, 63-82.

Bennett, B. and Love, G.D. (2000) Release of organic nitrogen compounds from kerogen via catalytic hydropyrolysis. Geochem. Trans. 1, 61.

Benning, L.G., Phoenix, V., Yee, N., Tobin, J.J., Konhauser, K.O., and Mountain, B.W. (2002) Molecular characterization of cyanobacterial cells during silicification: a synchrotron-based infrared study. Geochem. Earth's Surface 6, 259-263.

Boyce, C.K., Hazen, R.M., and Knoll, A.H. (2001) Nondestructive, in situ, cellular-scale mapping of elemental abundances including organic carbon in permineralized fossils. Proc. Natl. Acad. Sci. USA 98(11), 5970-5974.

Brasier, M.D., Green, O.R., Jephcoat, A.P., Kleppe, A.K., Van Kranendonk, M.J., Lindsay, J.F., Steele, A. and Grassineau, N.V. (2002). Questioning the evidence for earth's oldest fossils. Nature 416, 76-81.

Brasier, M.D., Green, O.R., Lindsay, J.F., and Steele, A. (2004). Earth's oldest ( $\sim 3.5 \mathrm{Ga})$ fossils and the 'Early Eden hypothesis': questioning the evidence. Origins of Life and Evolution of the Biosphere 34, 257-269.

Brasier, M.D., Green, O.R., Lindsay, J.F., McLoughlin, N., Jephcoat, A.P., Kleppe, A,K., Press, M., Steele, A., and Stoakes, C. (2005) Critical testing of Earth's oldest putative fossil assemblage from the $\sim 3.5 \mathrm{Ga}$ Apex chert, Chinaman Creek, Western Australia. Precambrian Res. 140, 55-102.

Brearley, A.J. (2003) Ubiquitous nanophase Fe, Ni carbides in Murchison fine-grained rims: possible relicts of Nebular Fischer-Tropsch reactions [abstract 5262]. In $66^{\text {th }}$ Annual Meteoritical Society Meeting, Munster, Germany, The Meteoritical Society

Brocks, J.J. and Summons, R.E. (2004) Sedimentary hydrocarbons, biomarkers for early life. In Treatise on Geochemistry, Vol. 8: Biogeochemistry, edited by W. H. Schlesinger, Elsevier, Oxford, pp. 63-115.

Cady, S.L., Farmer, J.D., Grotzinger, J.P., Schopf, J.W., and Steele, A. (2003) Morphological biosignatures and the search for life on Mars. Astrobiology 3(2), 351-368. 
Des Marais, D.J. (2003) Biogeochemistry of hypersaline microbial mats illustrates the dynamics of modern microbial ecosystems and the early evolution of the biosphere. Biol. Bull. 204, 160-167.

Eglinton, T.I., Irvine, J.E., Vairavamurthy, A., Zhou, W., and Manowitz, B. (1993) Formation and diagenesis of macromolecular organic sulfur in Peru margin sediments. Org. Geochem. 22(3-5), 781-799.

Fagerbakke, K.M., Heldal, M., and Norland, S. (1996) Content of carbon, nitrogen, oxygen, sulfur and phosphorus in native aquatic and cultured bacteria. Aquatic Microb. Ecol. 10(1), 15-27.

Floss, C. Stadermann, F.J., Bradley, J., Dai, Z.R., Bajt, S. and Graham, G. (2004). Carbon and nitrogen isotopic anomalies in an anhydrous interplanetary dust particle, Science 303, 1355 - 1358.

Floss, C. and Stadermann, F.J. (2005) NanoSIMS D/H imaging of isotopically primitive interplanetary dust particles [abstract 1423]. In $36^{\text {th }}$ Lunar and Planetary Science Conference Abstracts [CD-ROM], LPI Contribution No. 1234, Lunar and Planetary Institute, Houston.

Fukuda, R, Ogawa, H., Nagata, T., and Koike, I. (1998) Direct determination of carbon and nitrogen contents of natural bacterial assemblages in marine environments. Appl. Environ. Microbiol. 64(9), 3352-3358.

García-Ruiz, J.M., Hyde, S.T., Carnerup, A.M., Christy, A.G., Van Kranendonk, M.J., and Welham, N.J. (2003) Self-assembled silica-carbonate structures and detection of ancient microfossils. Science 302(5648), 1194-1197.

Gibson, E.K. Jr., Clemett, S.J., Thomas-Keprta, K L., McKay, D.S., Wentworth, S.J., Robert, F., Verchovsky, A.B., Wright, I.P., Pillinger, C.T., Rice, T., and Van Leer, B. (2006) Observation and analysis of in situ carbonaceous matter in Nakhla: Part II [abstract 2039]. In $37^{\text {th }}$ Lunar and Planetary Science Conference Abstracts [CD-ROM], LPI Contribution No. 1303, Lunar and Planetary Institute, Houston.

Gillaizeau, B., Behar, F., Derenne, S, and Largeau, C. (1997) Nitrogen fate during laboratory maturation of a type I kerogen (Oligocene, Turkey) and related algaenan: nitrogen mass balances and timing of $\mathrm{N}_{2}$ production versus other gases. Energy Fuels 11(6), 1237-1249.

Hofmann, H.J. (2004) Archean microfossils and abiomorphs. Astrobiology 4(2), 135-136.

House, C.H., Schopf, J.W., McKeegan, K.D., Coath, C.D., Harrison, T M., and Stetter, K.O. (2000) Carbon isotopic composition of individual Precambrian microfossils. Geology 28(8), 707-710.

Kohnen, M.E.L., Sinninghe Damste, J.S., Ten Haven, H.L., and De Leeuw, J.W. (1989) Early incorporation of polysulphides in sedimentary organic matter. Nature 341, 640-641.

Kudryavtsev, A.B., Schopf, J.W., Agresti, D.G., and Wdowiak, T.J. (2001) In situ laser-Raman imagery of Precambrian microscopic fossils. Proc. Natl. Acad. Sci. USA 98(3), 823-826.

McKay, D.S., Clemett, S J., Thomas-Keprta, K.L., Wentworth, S.J., Gibson, E. K., Robert, F., Verchovsky, A. B., Pillinger, C. T., Rice, T., and Van Leer, B. (2006) Observation and analysis of in situ carbonaceous matter in Nakhla: Part I [abstract 2251]. In $37^{\text {th }}$ Lunar and Planetary Science Conference Abstracts [CDROM], LPI Contribution No. 1303, Lunar and Planetary Institute, Houston.

Nakamura-Messenger, K, Messenger, S., Keller, L.P., Clemett, S.J., and Zolensky, M.E. (2006) Organic globules in the Tagish Lake Meteorite: Remnants of the proto-solar disk. Science 314, 1439-1442.

Oehler, D.Z., Mostefaoui, S., Meibom, A., Selo, M., McKay, D.S., and Robert, F. (2006a) Chemical mapping of Proterozoic Organic matter at Submicron Spatial Resolution. Astrobiology 6 (6), 838-850.

Oehler, D.Z., Mostefaoui, S., Meibom, A., Selo, M., McKay, D.S., and Robert, F. (2006b) "Nano" morphology and element signatures of early life on Earth: a new tool for assessing biogenicity [abstract 1067]. In $37^{\text {th }}$ Lunar and Planetary Science Conference Abstracts [CD-ROM], LPI Contribution No. 1303, Lunar and Planetary Institute, Houston.

Oehler, D.Z., Mostefaoui, S., Meibom, A., Selo, M., McKay, D.S., and Robert, F. (2006c) NanoSIMS reveals new structural and elemental signatures of early life [Astrobiology Science Conference 2006, Washington D.C., NASA Astrobiology Institute, abstract 11]. Astrobiology 6 (1), 222-223.

Oehler, J.H. (1976) Experimental studies in Precambrian paleontology: structural and chemical changes in blue-green algae during simulated fossilization in synthetic chert. Geol. Soc. Am. Bull. 87, 117-129.

Oehler, J.H. and Schopf, J.W. (1971) Artificial microfossils: experimental studies of permineralization of blue-green algae in silica. Science 174, 1229-1231.

Phoenix, V.R., Adams, D.G., and Konhauser, K.O. (2000) Cyanobacterial viability during hydrothermal biomineralization. Chem. Geol. 169(3-4), 329-338.

Phoenix, R.R., Martinex, R.E., Konhauser, K.O., and Ferris, F.G. (2002) Characterization and inplications of the cell surface reactivity of Calothrix sp. strain KC97. Appl. Environ. Microbiol. 68(10), 4827-4834.

Remusat, L., Derenne, S., Robert, F., and Knicker, H. (2005) New pyrolitic and spectroscopic data on Orgueil and Murchison insoluble organic matter: a different origin than soluble? Geochim. Cosmochim. Acta 69(15), 3919-3932. 
Robert, F., Selo, M., and Skrzypczak, A. (2005) NanoSIMS images of Precambrian fossil cells [abstract 1314]. In $36^{\text {th }}$ Lunar and Planetary Science Conference Abstracts [CD-ROM], LPI Contribution No. 1234, Lunar and Planetary Institute, Houston.

Rushdi, A.I. and Simoneit, B.R.T. (2005) Abiotic synthesis of organic compounds from carbon disulfide under hydrothermal conditions. Astrobiology 5(6), 749-769.

Sandford, S.A. et al.,( 2006). Organics captured from Comet 81P/Wild 2 by the Stardust Spacecraft. Science 314 (5806), 1720-1724.

Schopf, J.W. (1968) Microflora of the Bitter Springs Formation, Late Precambrian, central Australia. J. Paleontol. 42(3), 651-668.

Schopf, J.W. (1993). Microfossils of the early Archaean Apex chert: new evidence of the antiquity of life Science 260, 640-646.

Schopf, J.W. (2002) Geochemistry and submicron-scale structure of individual Precambrian microfossils [paper 67-2]. In GSA Annual Meeting Abstracts 2002, Geological Society of America, Denver, CO.

Schopf, J.W. and Blacic, J.M. (1971) New microorganisms from the Bitter Springs Formation (Late Precambrian) of the north-central Amadeus Basin, Australia. J. Paleontol. 45(6), 925-961.

Schopf, J.W., Kudryavtsev, A.B., Agresti, D.G., Wdowiak, T.J., and Czaja, A.D. (2002) Laser-Raman imagery of Earth's earliest fossils. Nature 416(6876), 73-76.

Schopf, J.W., Kudryavtsev, S.B., and Tripathi, A. (2005a) Three dimensional optical and chemical imagery of Precambrian microscopic fossils [abstract 528]. In NASA Astrobiology Institute 2005 Biennial Meeting, Boulder, CO. NASA Astrobiology Institute.

Schopf, J.W., Kudryavtsev, A.B., Agresti, D.G., Czaja, A.D., and Wdowiak, T.J. (2005b) Raman imagery: new approach to assess the maturity and biogenicity of permineralized Precambrian fossils. Astrobiology 5(3), 333-371.

Skrzypczak, A.., Derenne, S., Robert, F., Binet, L., Gourier, D., J.-N. Rouzaud, J.-N., and Clinard, C. (2004). Characterization of the organic matter in an Archean Chert (Warrawoona, Australia). 35th LPSC, Abs. \# 1241.

Skrzypczak, A., Derenne, S., Binet, L., Gourier, D., and Robert, F. (2005) Characterization of a 3.5 billion year old organic matter: electron paramagnetic resonance and pyrolysis GC-MS. Tools to assess syngeneity and biogenicity [abstract 1351]. In $36^{\text {th }}$ Lunar and Planetary Science Conference Abstracts [CD-ROM], LPI Contribution No. 1234, Lunar and Planetary Institute, Houston.

Toporski, J.K.W., Steele, A., Westall, F., Thomas-Keprta, K.L., and McKay, D.S. (2002) The simulated silicification of bacteria - new clues to the modes and timing of bacterial preservation and implications for the search for extraterrestrial microfossils. Astrobiology 2(1), 1-26.

Ueno, Y, Yoshioka, H., Maruyama, S., and Isozaki, Y. (2004) Carbon isotopes and petrography of kerogens in $\sim 3.5$ Ga hydrothermal silica dikes in the North Pole area, Western Australia. Geochim. Cosmochim. Acta 68(3), 573-589.

Van Zuilen, M., Lepland, A. and Arrhenius, G. (2002). Reassessing the evidence for the earliest traces of life. Nature 418, 627-630.

Werne, J.P. (2002) The role of organic sulfur in global sulfur cycling: links to inorganic sulfur and microbial processes [paper no. 96-1]. In GSA Annual Meeting Abstracts 2002, Geological Society of America, Denver, CO.

Werne, J.P., Hollander, D.J., Behrens, A., Schaeffer, P., Albrecht, P., and Sinninghe Damste, J.S. (2000) Timing of early diagenetic sulfurization of organic matter: a precursor-product relationship in Holocene sediments of the anoxic Cariaco Basin, Venezuela. Geochim. Cosmochim. Acta 64(10), 1741-1751.

Yee, N., Phoenix, V.R., Konhauser, K.O., Benning, L.G., and Ferris, F.G. (2003) The effect of cyanobacterial on silica precipitation at neutral $\mathrm{pH}$ : implications for bacterial silicification in geothermal hot springs. Chem. Geol. 199(1-2), 83-90. 